\title{
POISONING ACCIDENTS IN CHILDHOOD
}

\author{
BY \\ T. MCKENDRICK \\ From the Paediatric Unit, Hillingdon Hospital, Uxbridge
}

(RECEIVED FOR PUBLICATION MAY 25, 1959)

The problem of accidents in the home has recently received much publicity and the Government has called for special efforts in dealing with it. Attention is being directed mainly to traumatic causes such as falls, burns and scalds. Of the 900 deaths annually due to domestic accidents in children aged less than 15 years in England and Wales, the vast majority are due to these causes. During the past decade, however, between 16 and 47 (average 32) every year have been due to accidental poisoning and relatively little interest has been shown in this group. Until more is known of the epidemiology of these accidents the problem of prevention cannot be faced.

Paucity of information on the subject is probably due to several factors. The very wide selection of potentially poisonous substances taken by children makes generalization of their effects and sources very difficult. Many poisoning accidents produce no clinical effects (other than parental anxiety) and as a result are not investigated. The fatality rate is very low and does not reveal the extent of the problem.

It is difficult to estimate how many poisoning accidents there are in this country each year. Although there are many papers dealing with small or selected series (Holzel and James, 1951; Spencer, 1951; Craig, 1953) or describing single cases (Kirby, 1955; Hurdle and Lane, 1956; Greenberg, 1957) there is only one large series (Craig and Fraser, 1953) which refers to poisons in general. The fatality rate in this was two in 502 cases. The series described below includes one death in 275 cases. These two series combined show a fatality rate of $0.4 \%$ but times, places and possibly case selection differ. Several large series in the U.S.A. (Jacobziner, 1956; Mellins, Christian and Bundesen, 1956; Dobson, Daeschner, Mondshine, Teng, Preble and Knudsen, 1957; Jacobziner and Raybin, 1957; Schroeder, 1957) totalled 14 deaths in about 3,100 children, a fatality rate of $0.45 \%$.

It seems likely, therefore, that for every death, about 250 children are admitted to hospital for observation or treatment of poisoning. This suggests a total of 7,000 or more such accidents in this country each year. Poisoning thus plays a considerable part in childhood morbidity. Some of the factors in its aetiology are considered below.

\section{Material}

The case histories were examined of all children aged less than 16 years who were brought to Hillingdon Hospital because of poisoning or suspected poisoning between January, 1946 and March, 1958. The total number was 292 . Seventeen were discarded as being irrelevant to this study of accidental poisoning by ingestion because they referred to coal gas poisoning (8), poisons deliberately taken or given (8) and poison absorbed from a raw skin surface (1). Of the remaining 275 children, 218 were admitted to the wards; the other 57 were treated in the casualty department. No child figured in more than one accident.

There were 156 boys and 119 girls. The average age of the boys was 2 years $10 \cdot 8$ months, that of the girls 2 years $8 \cdot 2$ months, and of the whole series 2 years 9.5 months. The age distribution is shown in Table 1. There was no appreciable difference in

TABLE 1

DISTRIBUTION OF POISONING CASES BY SEX AND AGE, JANUARY, 1946-MARCH, 1958

\begin{tabular}{c|c|c|c}
\hline Age (yr.) & Male & Female & Total \\
\cline { 2 - 3 } & (no.) & (no.) & (no.) \\
$0-1$ & 55 & 4 & 9 \\
$1-1 \frac{1}{2}$ & 15 & 10 & 25 \\
$1 \frac{1}{2}-2$ & 37 & 31 & 68 \\
$2-2 \frac{1}{2}$ & 32 & 26 & 58 \\
$2 \frac{1}{2}-3$ & 19 & 14 & 33 \\
$3-4$ & 21 & 14 & 35 \\
$4-5$ & 11 & 10 & 21 \\
$5-10$ & 13 & 10 & 23 \\
$10-16$ & 3 & 0 & 3 \\
\hline Total & 156 & 119 & 275 \\
\hline
\end{tabular}

the age distribution between the sexes. The most susceptible age was between $1 \frac{1}{2}$ and $2 \frac{1}{2}$ years, this group including $46 \%$ of the total. 


\section{Incidence}

The distribution of the children throughout the period is shown in Table 2.

TABLE 2

NUMBER OF CHILDREN ACCIDENTALLY POISONED, 1946-1957

\begin{tabular}{c|c|c|c}
\hline Year & Number & Year & Number \\
\hline 1946 & 8 & 1952 & 21 \\
1947 & 7 & 1953 & 28 \\
1948 & 16 & 1954 & 25 \\
1949 & 16 & 1955 & 46 \\
1950 & 16 & 1956 & 39 \\
1951 & 13 & 1957 & 32 \\
& & Jan.-Mar.1958 & 8 \\
\hline
\end{tabular}

The population which the hospital serves has increased only slightly during the period under review. Except at the periphery of the area there has been no alternative hospital for such cases. The annual numbers are therefore approximately comparable and show the great increase in accidental poisoning as noted in Edinburgh and Aberdeen by Craig and Fraser (1953) during the past decade. The peak incidence during this period was in 1955 (see Fig. 1). It is too early yet to determine what the trend over the next few years will be.

Seasonal variation in the incidence of accidental poisoning has been noted in the U.S.A. (Jacobziner, 1956) where $60 \%$ of cases occurred in the first half of the year. In the present series a marked variation occurred fairly consistently throughout the period. The pattern however was different. Only $40 \%$ occurred in the first six months of the year. More striking was the fact that $57 \%$ occurred during the five summer months of May to September (Table 3). This excess in the summer months was not due wholly to the ingestion of seeds, berries and plants, for, of 24 cases of this type of poisoning, 16 occurred in the summer and eight in the winter. It seemed partly related to the longer daylight hours (see below) though the greater wandering about the house which summer warmth permits may have been contributory.

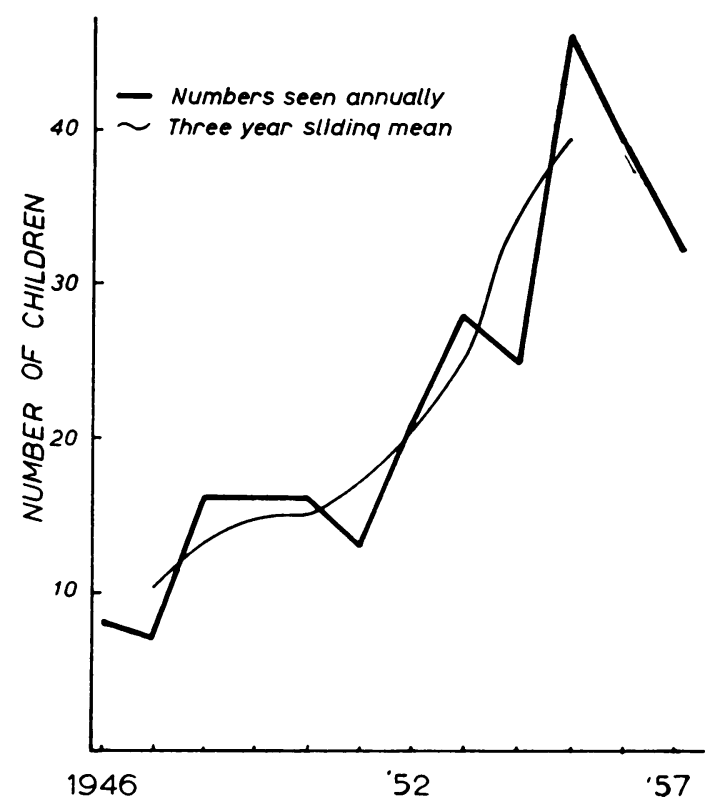

Fig. 1.-Annual numbers of children seen at Hillingdon Hospital because of accidental poisoning, 1946-57

Poisoning accidents occurred at nearly all hours of the day and night. Table 4 shows that the great majority (70\%) occurred between 11 a.m. and 7 p.m. Separation of the accidents into summer and winter incidences indicated that there was an excess of accidents between 5 and 7 p.m. during the summer months (Fig. 2). It may be that this summer evening excess can be ascribed to the fact that small children are active for much longer hours in the summer and are likely therefore to be tired and less easily controlled in the evening.

\section{Substances Swallowed}

The substances swallowed by the children are listed in Table 5. The total of 285 is accounted for by the fact that one child took three substances and eight took two each.

TABLE 3

NUMBER OF POISONING CASES BY MONTH IN THREE-YEAR PERIODS, 1946-1957

\begin{tabular}{|c|c|c|c|c|c|c|c|c|c|c|c|c|}
\hline Period & Jan. & Feb. & Mar. & Apr. & May & June & July & Aug. & Sept. & Oct. & Nov. & Dec \\
\hline $\begin{array}{l}1946-48 \\
1949-51 \\
1952-54 \\
1955-57\end{array}$ & $\begin{array}{l}2 \\
2 \\
1 \\
6\end{array}$ & $\begin{array}{l}1 \\
3 \\
4 \\
3\end{array}$ & $\begin{array}{r}3 \\
2 \\
3 \\
16\end{array}$ & $\begin{array}{l}2 \\
2 \\
4 \\
4\end{array}$ & $\begin{array}{r}1 \\
13 \\
13 \\
8\end{array}$ & $\begin{array}{r}5 \\
5 \\
9 \\
10\end{array}$ & $\begin{array}{r}2 \\
2 \\
8 \\
16\end{array}$ & $\begin{array}{r}7 \\
7 \\
9 \\
14\end{array}$ & $\begin{array}{r}4 \\
5 \\
9 \\
15\end{array}$ & $\begin{array}{l}0 \\
9 \\
7 \\
8\end{array}$ & $\begin{array}{l}\mathbf{1} \\
\mathbf{2} \\
\mathbf{3} \\
\mathbf{7}\end{array}$ & $\begin{array}{r}1 \\
5 \\
4 \\
10\end{array}$ \\
\hline Total & 11 & 11 & 24 & 12 & 25 & 29 & 28 & 37 & 33 & 24 & 13 & 20 \\
\hline
\end{tabular}

Total for May-Sept. $=152$

Total for Oct.-Apr. $=115$ 
TABLE 4

NUMBER OF POISONING ACCIDENTS BY HOUR OF DAY, SUMMER AND WINTER, AND HOURLY INCIDENCE, SUMMER AND WINTER (1946-1957)

\begin{tabular}{|c|c|c|c|c|c|c|c|c|c|c|c|}
\hline \multirow{2}{*}{ Time } & \multicolumn{3}{|c|}{ Number } & \multicolumn{2}{|c|}{ Corrected Rate* } & \multirow{2}{*}{ Time } & \multicolumn{3}{|c|}{ Number } & \multicolumn{2}{|c|}{ Corrected Rate* } \\
\hline & Total & Summer & Winter & Summer & Winter & & Total & Summer & Winter & Summer & Winter \\
\hline $\begin{array}{c}\text { midnight } \\
1- \\
2- \\
3- \\
4- \\
5- \\
6- \\
7- \\
8- \\
9- \\
10- \\
11-\text { noon }\end{array}$ & $\begin{array}{r}2 \\
\\
1 \\
6 \\
13 \\
8 \\
12 \\
21\end{array}$ & $\begin{array}{r}1 \\
\\
4 \\
7 \\
6 \\
4 \\
11\end{array}$ & $\begin{array}{r}1 \\
\\
1 \\
2 \\
6 \\
2 \\
8 \\
10\end{array}$ & $\begin{array}{r}1 \cdot 2 \\
\\
4 \cdot 8 \\
8 \cdot 3 \\
7 \cdot 2 \\
4 \cdot 8 \\
13 \cdot 1\end{array}$ & $\begin{array}{l}0.9 \\
\\
0.9 \\
1 \cdot 7 \\
5 \cdot 2 \\
1 \cdot 7 \\
6 \cdot 9 \\
8 \cdot 6\end{array}$ & $\begin{array}{c}\text { noon } \\
1- \\
2- \\
3- \\
4- \\
5- \\
6- \\
7- \\
8- \\
9- \\
10- \\
11- \\
\text { midnight }\end{array}$ & $\begin{array}{l}18 \\
16 \\
12 \\
33 \\
25 \\
17 \\
22 \\
13 \\
7 \\
5 \\
2\end{array}$ & $\begin{array}{r}6 \\
5 \\
8 \\
18 \\
14 \\
14 \\
14 \\
7 \\
3 \\
3 \\
1\end{array}$ & $\begin{array}{r}12 \\
11 \\
4 \\
15 \\
11 \\
3 \\
8 \\
6 \\
4 \\
2 \\
1\end{array}$ & $\begin{array}{r}7 \cdot 2 \\
6 \cdot 0 \\
9 \cdot 5 \\
21 \cdot 4 \\
16 \cdot 7 \\
16 \cdot 7 \\
16 \cdot 7 \\
8 \cdot 4 \\
3 \cdot 6 \\
3 \cdot 6 \\
1 \cdot 2\end{array}$ & $\begin{array}{r}10.3 \\
9.5 \\
3.4 \\
12.9 \\
9.5 \\
2.6 \\
6.9 \\
5.2 \\
3.4 \\
1.7 \\
0.9\end{array}$ \\
\hline
\end{tabular}

Number of accidents with time not recorded $=42$ period under

The list is essentially similar to that of Craig and Fraser (1953), though the proportions of the groups of poisons differ slightly. Table 6 and Fig. 3 show the change in the incidence of the various groups throughout the period. Here several differences become apparent.
Within the medicament group several trends are apparent. The frequency of aspirin poisoning has been much enhanced since 1952 by baby type aspirin. Since that year 19 children have been admitted after taking an average of 30 grains of this type of aspirin. Hyoscine, in the form of antimotion sickness tablets, has, since about the same time, joined the commonest substances taken. In this area ferrous sulphate is much less often a source of poisoning than in the North. Poisoning with the anti-histamines is also rare. Table 7 illustrates these points. The suggestion that coloured tablets may be more attractive than white ones gains some support from this series. Of the 114 tablets listed, 65 were coloured, 45 were grey or white and in four the colour was not known. In the absence of information on the relative numbers of each available, however, no firm conclusion can be drawn as to why this was so. The only fatality in this series occurred in the following circumstances.
The great disparity between the increases of accidental poisoning by medicaments and by household materials, clearly shown in the Scottish series, is not seen in this series. In fact, with the exception of 1955 , each year has seen an approximately similar rise in both groups. 
The tablets were later found to contain iron and strychnine.

TABLE 5

ANALYSIS OF SUBSTANCES TAKEN

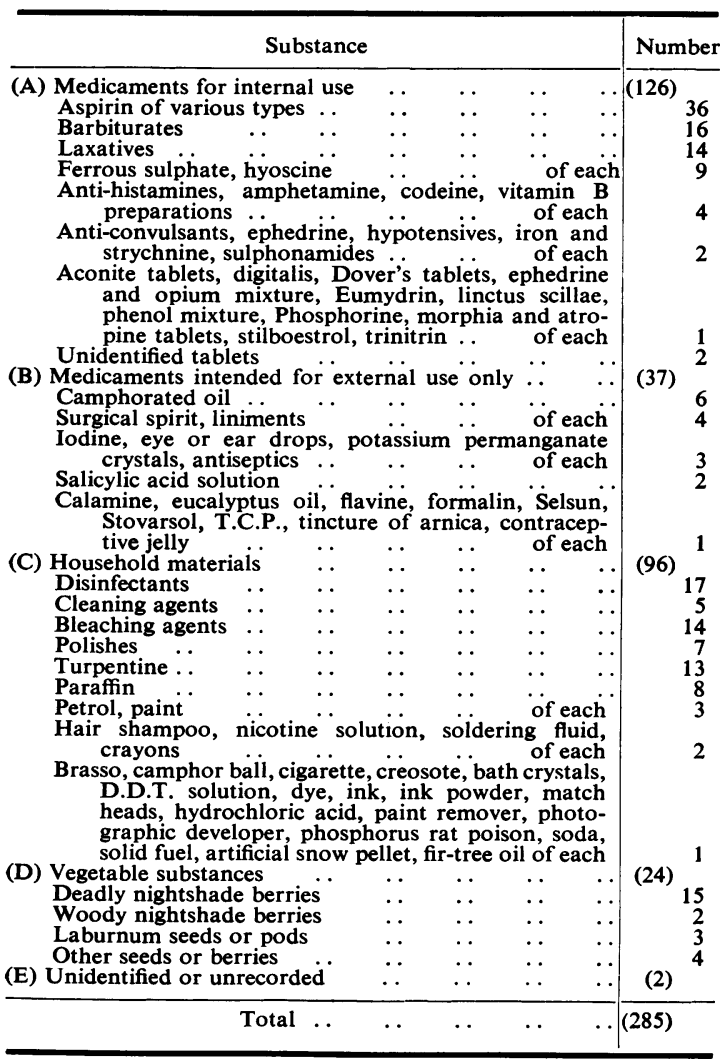

\section{Source of Poisons}

Detailed information was sought from the parents of the last 150 children seen (i.e. all those seen after January, 1954) as to how and where the poisons were obtained. In about half these cases the enquiry was retrospective. Nine could not be traced and eight did not reply. There were five accidents each involving two children; these have been counted as single incidents.

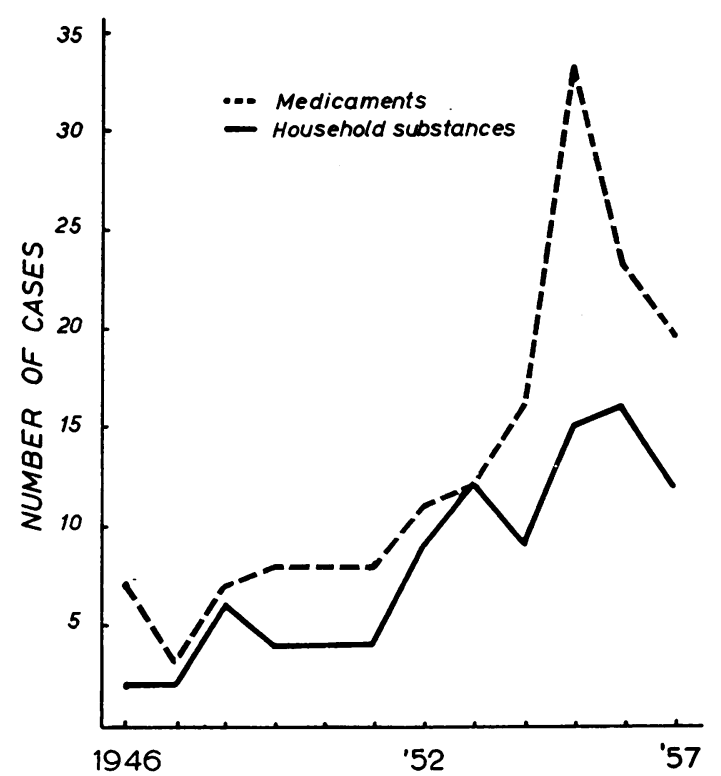

Fig. 3.-Annual incidence of poisoning accidents due to medicaments and household substances, 1946-57

TABLE 7

NUMBER OF ACCIDENTS DUE TO CERTAIN DRUGS, BY THREE-YEAR PERIODS, 1946-1957

\begin{tabular}{|c|c|c|c|c|}
\hline Substance & $1946-48$ & 1949-51 & $1952-54$ & $1955-57$ \\
\hline $\begin{array}{l}\text { Aspirin* }_{\text {Baby type aspirin }} \\
\begin{array}{l}\text { Barbiturates } \\
\text { Laxatives }\end{array}\end{array}$ & $\begin{array}{l}4 \\
0 \\
1 \\
3 \\
3 \\
0\end{array}$ & $\begin{array}{l}1 \\
0 \\
4 \\
2 \\
1 \\
1\end{array}$ & $\begin{array}{l}4 \\
5 \\
5 \\
3 \\
3 \\
4\end{array}$ & $\begin{array}{r}10 \\
14 \\
6 \\
4 \\
2 \\
4\end{array}$ \\
\hline
\end{tabular}

* Including preparations with codeine

Room Concerned. The places in which poisons were obtained are listed in Table 8 . In only 12 incidents was the poison obtained from a room other than that where it was normally kept. Comparison with two similar surveys made in the U.S.A. (Jacobziner and Raybin, 1956; Mellins et al., 1956) shows that in this area comparatively fewer dangerous substances were obtained from bedrooms and kitchen, but more from the living rooms.

TABLE 6

ANNUAL INCIDENCE BY POISON GROUP

\begin{tabular}{|c|c|c|c|c|c|c|c|c|c|c|c|c|c|}
\hline Substance & & 1946 & 1947 & 1948 & 1949 & 1950 & 1951 & 1952 & 1953 & 1954 & 1955 & 1956 & 1957 \\
\hline $\begin{array}{l}\text { Tablets } \\
\text { All other medicaments } \\
\text { All medicaments . } \\
\text { Household materials } \\
\text { Vegetable substances }\end{array}$ & $\begin{array}{l}\cdots \\
\cdots \\
\cdots \\
\cdots\end{array}$ & $\begin{array}{l}3 \\
4 \\
7 \\
2 \\
0\end{array}$ & $\begin{array}{l}3 \\
0 \\
3 \\
2 \\
1\end{array}$ & $\begin{array}{l}6 \\
1 \\
7 \\
6 \\
2\end{array}$ & $\begin{array}{l}5 \\
3 \\
8 \\
4 \\
4\end{array}$ & $\begin{array}{l}4 \\
4 \\
8 \\
4 \\
4\end{array}$ & $\begin{array}{l}6 \\
2 \\
8 \\
4 \\
1\end{array}$ & $\begin{array}{r}7 \\
4 \\
11 \\
9 \\
1\end{array}$ & $\begin{array}{r}9 \\
3 \\
12 \\
12 \\
4\end{array}$ & $\begin{array}{r}13 \\
3 \\
16 \\
9 \\
0\end{array}$ & $\begin{array}{r}21 \\
12 \\
33 \\
15 \\
3\end{array}$ & $\begin{array}{r}14 \\
9 \\
23 \\
16 \\
2\end{array}$ & $\begin{array}{r}18 \\
1 \\
19 \\
12 \\
2\end{array}$ \\
\hline
\end{tabular}


TABLE 8

LOCATION OF POISONS

\begin{tabular}{|c|c|c|c|c|c|}
\hline \multicolumn{5}{|c|}{ Place } & Number \\
\hline $\begin{array}{l}\text { Kitchen } \ldots \text {. . } \\
\text { Living and dining rooms } \\
\text { Bedrooms } \quad \ldots \\
\text { Bathroom } \quad \ldots \\
\text { Sheds, garages, greenhouses } \\
\text { Empty rooms, caravans, etc. } \\
\text { Garden . } \quad . . \\
\text { Not known or not recorded }\end{array}$ & $\begin{array}{l}\cdots \\
\cdots \\
\cdots \\
\cdots \\
\cdots \\
\cdots\end{array}$ & $\begin{array}{l}\cdots \\
\cdots \\
\cdots \\
\cdots \\
\cdots \\
\cdots\end{array}$ & $\begin{array}{l}\cdots \\
\cdots \\
\cdots \\
\cdots \\
\cdots \\
\cdots\end{array}$ & $\begin{array}{l}\cdots \\
\cdots \\
\cdots \\
\cdots \\
\cdots \\
\cdots\end{array}$ & $\begin{aligned} 38 & (26 \cdot 2 \%) \\
35 & (24 \cdot 1 \%) \\
24 & (16 \cdot 5 \%) \\
8 & (5 \cdot 5 \%) \\
8 & (5 \cdot 5 \%) \\
8 & (5 \cdot 5 \%) \\
10 & (7.0 \%) \\
14 & (9 \cdot 6 \%)\end{aligned}$ \\
\hline
\end{tabular}

Site within Room. Within rooms there was considerable variation both as to where the poison was kept and where it was actually found (Table 9).

TABLE 9

NUMBER OF POISONS TAKEN BY SITE OF STORAGE AND SITE WHERE FOUND

\begin{tabular}{|c|c|c|c|c|}
\hline & \multicolumn{2}{|c|}{ Drugs } & \multicolumn{2}{|c|}{$\begin{array}{c}\text { Household } \\
\text { Material }\end{array}$} \\
\hline & $\begin{array}{r}\text { Normal- } \\
\text { ly Stored }\end{array}$ & Found & $\begin{array}{r}\text { Normal- } \\
\text { ly Stored }\end{array}$ & Found \\
\hline $\begin{array}{l}\text { On tables, dressers, sideboards } \\
\text { Open shelves . } \\
\text { Sills, mantel shelves, draining }\end{array}$ & $\begin{array}{l}6 \\
8\end{array}$ & $\begin{array}{r}17 \\
6\end{array}$ & $\begin{array}{r}5 \\
16 \\
\end{array}$ & $\begin{array}{r}21 \\
7\end{array}$ \\
\hline \begin{tabular}{lll}
\multicolumn{1}{c}{ boards } & $\ldots$ & $\cdots$ \\
Other open places & $\cdots$ & $\ldots$ \\
In cupboards ... & $\cdots$ & \\
In bathroom or medicine cabi-
\end{tabular} & $\begin{array}{r}2 \\
0 \\
19\end{array}$ & $\begin{array}{r}9 \\
4 \\
11\end{array}$ & $\begin{array}{r}1 \\
0 \\
19\end{array}$ & $\begin{array}{r}3 \\
10 \\
8\end{array}$ \\
\hline $\begin{array}{cccc}\text { nets } & \ldots & \ldots & \ldots \\
\text { In drawers } & \ldots & \ldots & \cdots \\
\text { No fixed place } & \cdots & \cdots \\
\text { Not normally kept in house- } \\
\text { hold } \\
\text { Information not available } & \cdots\end{array}$ & $\begin{array}{r}13 \\
10 \\
4 \\
1 \\
19\end{array}$ & $\begin{array}{r}5 \\
9 \\
- \\
15\end{array}$ & $\begin{array}{l}1 \\
\mathbf{0} \\
\mathbf{0} \\
\mathbf{8} \\
\mathbf{7}\end{array}$ & $\begin{array}{l}\frac{1}{0} \\
- \\
4\end{array}$ \\
\hline 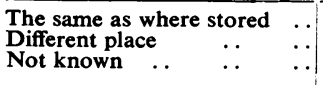 & & $\begin{array}{l}35 \\
27 \\
14\end{array}$ & & $\begin{array}{r}22 \\
29 \\
6\end{array}$ \\
\hline
\end{tabular}

Excluded from this Table are (a) the vegetable group (7); (b) drugs given in error by parents from column 'Drugs Found' (6); (c) substances the sources of which remain unknown (3).

Clearly, one important factor in the aetiology of accidental poisoning is the frequency with which drugs and household materials are left easily accessible. Though there was a tendency to leave drugs in open positions temporarily rather than permanently, some strange places of storage came to light. A tin box on top of the television set, a dressing-gown pocket and a low, unlocked, glass-fronted cabinet were all used as medicine stores. In 11 of the 35 instances when a medicament was found in its normal place, there were other, sometimes more dangerous, substances present.

It is frequently stated that medicines kept under lock and key are safe from children. Of the 82 incidents involving medicaments, however, this good habit had been invalidated in 14 by various factors. Thus, two locked cupboards were opened, not by the children who took the medicaments, but by elder siblings who had found the keys. In one incident a drawer 'always kept locked' was for once left open, and in four more the medicament was inadvertently 'left out'. Such situations may be ascribed to carelessness but the following are less easy to condemn. On three occasions drugs just bought were put temporarily with other contents of the shopping basket on the kitchen table before being locked up, only to be found within a few minutes by curious toddlers. Finally, four enterprising opportunists, aged from 11 months to 2 years, grabbed tablets within a few seconds of their being taken out for administration to others.

Height alone seemed to be of little protective value. Fourteen children obtained poisons from shelves or cupboards more than $5 \mathrm{ft}$. from the ground. No less than 40 are recorded as having climbed to reach the poison. Their average age of $2 \frac{1}{2}$ years is slightly less than that of the group as a whole, but boys outnumbered girls by three to one. Three of these children were aged less than 18 months. Perhaps the most ingenious climb was that of R.B. in Example 1.

EXAMPLE 1. R.B., aged 1 year 9 months, climbed up the ill-fitting and partly opened drawers of a dresser in a garden shed. Clinging on to the handles, he reached a bottle of soldering fluid on a shelf $6 \mathrm{ft}$. above ground.

Some of the value of relative inaccessibility is reduced when parents call medicinal tablets 'sweets' as an inducement to toddlers to accept them. The following examples illustrate some of the above factors:

EXAMPLE 2. S.C., aged 3 years, left his bed at 10 p.m., went into the kitchen, climbed with the help of a chair on to the dresser and opened a high wall cupboard. Ignoring seven other medicaments and disinfectants, he took a substantial amount of flavoured and coloured aspirin tablets. The mother had earlier in the day given him two of these 'sweeties' to help his cold. At the time of this incident both parents heard him but each assumed, being in different rooms, that it was the other who was opening the cupboard.

EXAMPLE 3. S.H., aged $1 \frac{1}{2}$ years, was given approximately $60 \mathrm{gr}$. of ferrous sulphate by her brother, aged 3 years, about 11.30 a.m. He brought a chair from the living room into the kitchen so that he could climb on to the dresser, having first found the key to unlock the top cupboard where mother kept her 'green sweets'.

Container. The variety of container from which the substances were taken was fairly restricted and is shown in Tables 10 and 11.

The pattern is similar to that reported by Mellins et al. (1956). On only 11 occasions had the substance been transferred from its original container to one less suitable. The proportion $(7 \%)$ is much 
TABLE 10

TYPES OF CONTAINER FROM WHICH POISONS WERE TAKEN

\begin{tabular}{|c|c|c|c|c|c|c|c|}
\hline \multicolumn{7}{|c|}{ Container } & \multirow{2}{*}{$\begin{array}{c}\text { Number } \\
83 \\
4 \\
16 \\
25 \\
4 \\
2 \\
6 \\
12\end{array}$} \\
\hline $\begin{array}{l}\text { Bottle .. } \\
\text { Plastic or glass tube } \\
\text { Tin .. } \\
\text { Cardboard box } \\
\text { Cup or open can } \\
\text { Envelope } \ldots \\
\text { No container . } \\
\text { Not known . }\end{array}$ & $\begin{array}{l}\cdots \\
\cdots \\
\cdots \\
\cdots \\
\cdots \\
\cdots\end{array}$ & $\begin{array}{l}\ldots \\
\ldots \\
\cdots \\
\cdots \\
\ldots \\
\ldots\end{array}$ & $\begin{array}{l}\ldots \\
\ldots \\
\cdots \\
\ldots \\
\cdots \\
\cdots\end{array}$ & $\begin{array}{l}\cdots \\
\cdots \\
\cdots \\
\cdots \\
\cdots \\
\cdots\end{array}$ & $\begin{array}{l}\cdots \\
\cdots \\
\cdots \\
\cdots \\
\ldots \\
\ldots\end{array}$ & $\begin{array}{l}\ldots \\
\ldots \\
\ldots \\
\ldots \\
\ldots \\
\ldots\end{array}$ & \\
\hline
\end{tabular}

TABLE 11

TYPES OF CLOSURE OF CONTAINERS LISTED IN TABLE 10

\begin{tabular}{|c|c|c|c|c|c|c|}
\hline \multicolumn{6}{|c|}{ Closure } & \multirow{2}{*}{$\begin{array}{c}\text { Number } \\
67 \\
20 \\
2 \\
4 \\
3 \\
10\end{array}$} \\
\hline $\begin{array}{l}\text { Screw cap } \\
\text { Cork } \\
\text { Plastic bung } \\
\text { Fit-over tin lid } \\
\text { Fit-in tin lid } \\
\text { No closure }\end{array}$ & $\begin{array}{l}. . \\
\ldots \\
\cdots \\
\ldots\end{array}$ & $\begin{array}{l}\ldots \\
\ldots \\
\cdots \\
\cdots\end{array}$ & $\begin{array}{l}. \\
\because \\
\because \\
\because \\
\therefore\end{array}$ & $\begin{array}{l}. . \\
\because \\
\because \\
\cdots\end{array}$ & $\begin{array}{l}. . \\
\because . \\
\because \\
\therefore\end{array}$ & \\
\hline
\end{tabular}

Cardboard boxes, containers not designed to have lids and instances where there was either no container or where its nature was unknown have been excluded.

smaller than those recorded by Mellins et al. (1956) and Jacobziner and Raybin (1956), $40 \%$ and $30 \%$ respectively. Of these 11, eight involved paraffin or turpentine. It seemed significant that, of the nine bottles or jars without a lid, six contained one of these two substances. As paraffin or turpentine figured in a total of 14 incidents, it appeared that unusually casual handling of them was to some extent responsible for these accidents. This observation apart, study of the containers revealed little of importance. All the common types were represented. Frequently they are most unsafe. Dangerous drugs are supplied in envelopes or flimsy boxes; glass bottles are easily broken, especially when small hands reach high up to grip them; corks can be pulled out by toddlers' teeth when their fingers are not strong enough.

As might be expected, labelling was of little direct importance in the majority of poisoning accidents in young children. In the 14 incidents involving children over the age of 5 years, in only two was the substance labelled. In one instance the child was misled by the wrong label. Adequate labelling, however, ought to warn parents to take care in the storage of harmful substances, yet no less than 27 substances clearly labelled as dangerous were left easily accessible.

EXAMPLE 4. J.H., aged 2 years, took a plastic tube full of hyoscine tablets from a dressing table drawer which was never locked. Asked if the tube was labelled, father replied 'Yes, but it's of no consequence at his age'; yet the label stated 'CAUTION. It is dangerous to exceed the stated dosage'.
Labels such as the above were common. Very few stated unequivocally that the substance should be kept out of reach of children. Indeed one popular brand of analgesic bears a label stressing its safety and harmlessness without a warning of any kind; yet five children swallowed potentially harmful amounts.

Other Factors. Several other factors which occasionally operated are summarized below:

(1) Small children tend to be generous to each other. In this series 14 children were the innocent recipients of dangerous substances. The donors, 22 in number (for several incidents involved more than two children), ranged from 3 to 10 years of age and eight of them were over 7 years old. The older children acted thoughtlessly but not always stupidly and never with malicious intent.

(2) Parents may have their attention distracted by another child or visitor and leave dangerous substances within easy reach of youngsters. Seven examples of this were seen.

(3) Children visiting strange houses, which are normally without children, may become bored and wander away from adults to explore drawers or cupboards. This occurred four times.

(4) Whilst parents are moving house or decorating rooms medicines are apt to be left conveniently concentrated in one site, usually on the floor. This led to four accidents.

\section{Conclusions}

Nearly all these poisoning accidents occurred because the poison was too easily accessible to young children. Such a situation might be the result of several contributing factors; for example, inadequate furnishing and overcrowding in the home or curiosity, mischief and mental retardation in children. Much the most important factors, however, concerned the parents. Lack of appreciation of the exploratory abilities of children, ignorance of the danger of many household substances, carelessness and apathy in the use and storage of medicaments far outweighed truly accidental causes. This is illustrated by the summary of the causes of the 145 accidents investigated in detail (Table 12).

Though it might seem from this list that all the accidents in groups $A$ to $D$ (numbering 121 in all) could and therefore should have been prevented, this would assume a standard of knowledge, foresight and care far above that found in practice. In Examples 2 and 3 it would be difficult to accuse the parents of carelessness or stupidity. Study of the 120 accidents about which sufficient facts were known (excluding the garden group) suggested that 
TABLE 12

HUMAN FACTORS CAUSING 145 POISONING ACCIDENTS

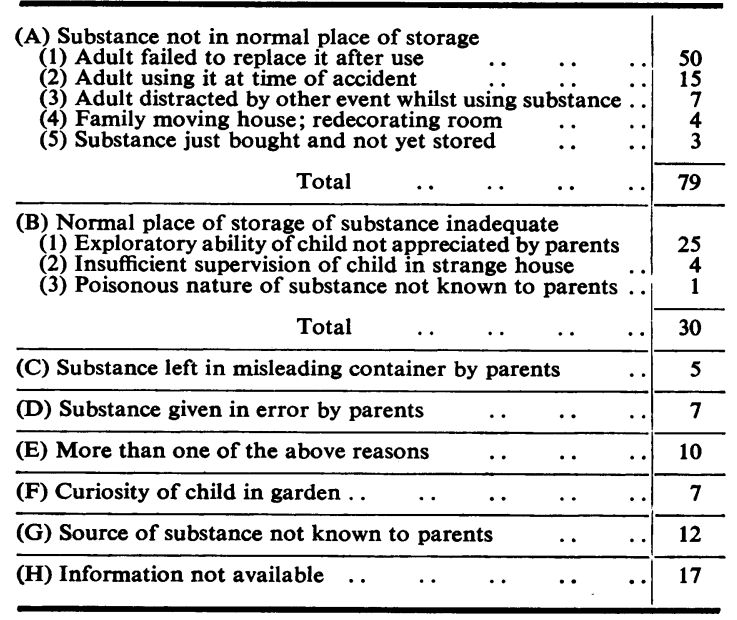

$38(32 \%)$ occurred without any obvious parental negligence. The other $82(68 \%)$ seemed easily preventable.

Apart from trying to overcome adult apathy, several simple direct measures are possible. Greater use could be made of short but prominent labels such as 'Keep out of the reach of children'. This is already done by many pharmacists but might be more effective if manufacturers incorporated such a warning on all packages containing medicaments other than those which are harmless even in gross overdosage. Even laxatives can be fatal (Craig and Fraser, 1953). It would also be valuable if similar warnings appeared with the common household poisons such as disinfectants, cleaning and bleaching agents, paraffin and turpentine.

Some accidents would be prevented were the common and dangerous tablet poisons (aspirin, barbiturates, ferrous sulphate, hyoscine and the antihistamines) always supplied in safety containers. These are merely small tins with snap-closing lids which young children are not strong enough to open. Unfortunately their relatively high cost would preclude their more extensive use. Finally, the tendency to store both medicaments and household materials in unsafe places might be reduced by providing safer storage facilities. Most new houses include several built-in cupboards. It would be neither difficult nor expensive to ensure that at least one in the kitchen and one in, say, a bedroom or the bathroom were fitted with a strong spring catch or similar safety device to defeat young hands.

\section{Summary}

The annual number of children accidentally poisoned in north-west Middlesex has greatly increased during the last 10 years. A study of 275 case histories over this period has shown that medicaments and household materials have contributed more or less equally to the rise.

The most susceptible age group was from $1 \frac{1}{2}$ to $2 \frac{1}{2}$ years of age. Relatively more accidents occurred during the summer months, the excess probably being due to longer daylight hours.

The commonest medicaments taken were aspirin, barbiturates, laxatives, ferrous sulphate and hyoscine. Disinfectants, bleaches, cleaning agents, turpentine and paraffin accounted for over half the household materials.

A more detailed study of 145 incidents showed that children obtained poisons from all parts of the house but most often from the kitchen and living room. Most of the substances taken had not been put away after use, were actually in use at the time, or were inadequately stored. Of this group, enough was known about 120 accidents to suggest that twothirds could have been readily prevented and that these could be traced to the action (or lack of action) of adults. Predominant were carelessness in handling or storing materials and failure to appreciate the ability of children.

Easily applicable methods which might decrease the number of such accidents include more frequent use of warning labels on drug packages and on the commoner household poisons, greater use of safety containers and provision in all new houses of at least two safety cupboards.

I wish to thank Dr. H. V. L. Finlay for his generous advice and criticism and constant encouragement. I am also indebted to Dr. W. A. Steel for permission to publish this investigation and for the facilities which made it possible. Finally my thanks are due to his secretarial and records staff, particularly Miss M. Burley and Miss M. E. Bates, whose patience and help was much appreciated, and to Miss Beckett for producing the graphs.

\section{REFERENCES}

Craig, J. O. (1953). Arch. Dis. Childh., 28, 475.

- and Fraser, M. S. (1953). lbid 28, 259.

Dobson, H. L., Daeschner, C. W., Mondshine, R., Teng, N., Preble, H. and Knudsen, J. M. (1957). Texas St. J.Med., 53, 514.

Greenberg, M. (1957). Arch. Dis. Childh., 32, 359.

Holzel, A. and James, T. (1951). Med. Offr, 86, 169.

Hurdle, A. D. F. and Lane, B. K. (1956). Lancet, 1, 836.

Jacobziner, H. (1956). J. Amer. med. Ass., 162, 454.

- and Raybin, H. W. (1956). J. Pediat., 49, 592.

- (1957). N. Y. St. J. Med., 57, 209.

Kirby, N. G. (1955). Lancet, $1,594$.

Mellins, R. B., Christian, J. R. and Bundesen, H. N. (1956). Pediatrics, 17, 314 .

Schroeder, A. J. (1957). Minn. Med., 40, 316.

Spencer, I. O. B. (1951). Brit. med. J., 2, 1112. 